\title{
Effects of saline lavage temperature on peritoneal fibrinolysis and adhesion formation
}

\author{
Yavuz Savaş Koca, M.D., ${ }^{1}$ Ömer Rıdvan Tarhan, M.D., ${ }^{1}$ Selçuk Kaya, M.D., ${ }^{2}$ Berit Gökçe Ceylan, M.D. ${ }^{3}$ \\ ${ }^{1}$ Department of General Surgery, Suleyman Demirel University Faculty of Medicine, Isparta, Turkey \\ 2Department of Medical Microbiology, Suleyman Demirel University Faculty of Medicine, Isparta, Turkey \\ ${ }^{3}$ Department of Anesthesiology and Reanimation, Suleyman Demirel University Faculty of Medicine, Isparta, Turkey
}

\begin{abstract}
BACKGROUND: Peritoneal lavage with saline at room temperature causes peritoneal hypothermia, vasoconstriction, hypoxia, and acidosis, which are effects that are known to reduce fibrinolysis. Decreased fibrinolysis causes permanent adhesions. Normothermic lavage may prevent this deleterious process and reduce peritoneal adhesions.

METHODS: A rat model of cecal abrasion was used. Control animals received no medication while hypothermic or normothermic saline lavage were administered intraperitoneally to the experimental groups ( $n=24$ for each group). Cardinal parameters of peritoneal fibrinolysis (tissue plasminogen activator [tPA] and plasminogen activator inhibitor type I [PAI-I]) were determined in peritoneal tissue samples on postoperative day I, 3 , and 10. On postoperative day 10 , adhesions were graded. In the sham group ( $\mathrm{n}=8$ ), following laparotomy, peritoneal samples were taken to determine basal values of tPA and PAI-I in healthy peritoneum.
\end{abstract}

RESULTS: Cecal abrasion increased PAI-I levels about tenfold on postoperative day I and caused adhesions. Normothermic saline lavage prevented this traumatic PAI-I increase and stabilized it to baseline values throughout the experiment and reduced peritoneal adhesion formation. Hypothermic lavage also caused an inhibition of PAI-I rise but adhesion, prevention was not significant.

CONCLUSION: Our results suggest that normothermic saline lavage reduces adhesions by improving peritoneal fibrinolysis.

Keywords: Hypothermic; normothermic; peritoneal adhesion; peritoneal lavage; plasminogen activator inhibitor I; saline solution; tissue plasminogen activator.

\section{INTRODUCTION}

Postoperative peritoneal adhesions affect the quality of life of millions of people all over the world, making intestinal obstruction, complicating reoperative laparotomy (an average of $24 \mathrm{~min}$ of increased operative time and $21 \%$ increased risk of bowel perforation), and causing chronic abdominal and pelvic pain and infertility. ${ }^{[1]}$ The formation of intra-abdominal adhesions after major abdominal surgery is inevitable.

An epidemiological study conducted in 1999 by Ellis et al.

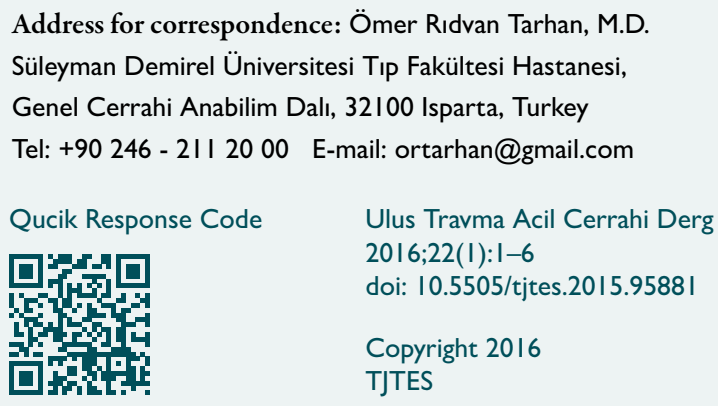

showed that one in three patients (34.7\%) who had undergone open surgery experienced a mean of 2.1 readmissions over the ten years. ${ }^{[1]}$

Therefore, preventive measures against adhesion formation are of considerable clinical importance. Physical separation for adhesion prophylaxis can potentially be achieved by using solid or mechanical barriers or by intraperitoneal solutions.

Fibrin matrix that was formed after peritoneal injury is broken down via peritoneal fibrinolysis and absorbed under normal circumstances. Fibrinolysis is mainly activated by tissue plasminogen activator (tPA), and principal tPA inhibitor is plasminogen activator inhibitor (PAI) type I. Ischemia reduces fibrinolytic capacity, and fibrin matrix changes permanent adhesions.

According to a questionnaire survey, peritoneal lavage is sometimes performed at least by $91 \%$ of the surgeons during elective laparotomy, and $68 \%$ of the surgeons use lavage for prophylaxis against adhesion formation, and normal saline is used most frequently. ${ }^{[2]}$ 
However, little is known about what the temperature of lavage solution should be. Essentially, temperatures of solutions are rarely described in adhesion studies. Possibly, these solutions are at room temperature. Three different results have been observed in peritoneal saline lavage; beneficial, ineffective or even harmful.

Tissue hypothermia is a serious problem. Hypothermia impairs tissue perfusion by causing vasoconstriction and leads to acidosis. ${ }^{[3]}$ Cold hemoglobin also cannot release oxygen to tissues as readily as normothermic hemoglobin. Peritoneal hypoxia and acidosis reduce peritoneal fibrinolysis. ${ }^{[4]}$ Hypothermia also induces coagulopathy, promoting further hemorrhage. It was our hypothesis that normothermic lavage might prevent this deleterious process, improve peritoneal fibrinolysis and reduce peritoneal adhesions. Hence, the effects of normal saline were examined at body temperature and room temperature on peritoneal adhesion formation and peritoneal fibrinolysis in a rat model.

\section{MATERIALS AND METHODS}

Animals

The ethics committee of our institution approved the experimental procedures in the study. Animals were obtained from the animal breeding unit of our university, and the guiding principles in the care and use of laboratory animals were strictly adhered throughout the entire study.

Sixty male adult wistar rats (weight, $270 \pm 30 \mathrm{~g}$ ) were used. Throughout the study period, animals were given food and water ad libitum. Animals were assigned into four groups randomly: Sham $(n=8)$, control $(n=24)$, normothermic saline $\left(37^{\circ} \mathrm{C}\right)(\mathrm{n}=24)$, and hypothermic saline (saline at room temperature, $\left.21^{\circ} \mathrm{C}\right)(\mathrm{n}=24)$ groups.

\section{Anesthesia and Experimental Design}

Initially, all of the rats $(n=80)$ were anesthetized with $50 \mathrm{mg} /$ kg ketamine hydrochloride (Ketalar ${ }^{\circledR}$; Parke - Davis, Morris Plains, New Jersey, USA), and $2.5 \mathrm{mg} / \mathrm{kg}$ xylazine hydrochloride (Rompun ${ }^{\circledR}$; Bayer, Istanbul, Turkey) intramuscularly. The abdomen was shaved and disinfected with $70 \%$ povidone iodine. All surgical procedures were carried out under sterile conditions. Following a $3-\mathrm{cm}$ midline incision, antimesenteric border of the cecum was abraded with dry sterile gauze until punctate bleeding occurred. Twenty times rubbing typically provided punctate bleeding.

No medication was administered to control animals. Animals in the normothermic saline group were given $5 \mathrm{ml}$ of intraperitoneal normal saline at $37^{\circ} \mathrm{C}$. After 2.5 minutes, the fluid was aspirated through a catheter. This procedure was repeated 5 times. The same procedure was performed using normal saline at $21^{\circ} \mathrm{C}$ temperature in the hypothermic saline group. In the sham group following laparotomy, peritoneal samples were taken to determine t-PA, PAI-I levels in the healthy rat peritoneum. Neither cecal abrasion nor peritoneal lavage was performed in this group.

Abdominal wall and skin were closed using 3-0 polypropylene (Prolene ${ }^{\circledR}$; Ethicon, Woluwe, Belgium) and 3-0 polyglactine $\left(V_{i c r y}{ }^{\circledR}\right.$; Ethicon, Woluwe, Belgium) continuous sutures, respectively.

On postoperative days I, 3, and 10, a U-shaped abdominal incision was made using the previously described anesthetical method (8 animals in each three experimental groups). Tissue specimens were obtained from an adhesion-free segment of the right lower quadrant peritoneum while the animals were alive. Following peritoneal incision with a $10-\mathrm{mm}$ biopsy punch, the peritoneal disc was carefully dissected off the underlying tissue, rinsed with normal saline solution, and dried with a piece of blotting paper to remove blood. All specimens were stored at $-80^{\circ} \mathrm{C}$ in airtight tubes until homogenization.

Abdominal cavity was explored for adhesions 10 days after laparotomy. Intraabdominal adhesions were graded according to Akdeniz et al. ${ }^{[5]}$ shown on Table I. Adhesion scores were determined by one of the investigators (YSK) blind to the randomization of the groups.

\section{Homogenization and Assays for tPA, and PAI-1}

After the biopsy specimens were homogenized in an Ultra Thurrax IKA T - 25 homogenizer (Janke \& Kunken, Staufen, Germany) for $3 \mathrm{~min}$, the homogenates were sonicated (Bandelin Electronic, Berlin, Germany) for 30 s. Following centrifugation at $4000 \mathrm{~g}$ for $20 \mathrm{~min}$, supernatants were stored at $-80^{\circ} \mathrm{C}$ until assay. tPA and PAI-I were determined by enzyme-linked immunosorbent assay in accordance with the manufacturer's instructions (Rat tPA and PAI-I Total Antigen Assay Kits, Molecular Innovations Inc, Novi, Michigan, USA). The absorbencies of wells were measured in a micro plate reader. Standard curves were obtained for each parameter separately through absorbance values of standard solutions. The concentrations of tPA and PAI-I were calculated using these curves.

Table I. Adhesion grading scale

\begin{tabular}{ll}
\hline Grade & Definitions \\
\hline 0 & $\begin{array}{l}\text { No adhesions } \\
\text { I }\end{array}$ \\
2 & $\begin{array}{l}\text { Filmy, avascular adhesions, separated easily by blunt } \\
\text { firsection, limited vascular adhesions, separated by } \\
\text { aggressive blunt dissection }\end{array}$ \\
3 & $\begin{array}{l}\text { Dense, well vascularized adhesions, needed sharp } \\
\text { dissection }\end{array}$ \\
\end{tabular}




\section{Assays for Protein}

The protein contents of the supernatants were assayed with the Lowry method. ${ }^{[6]}$ tPA and PAI-I concentrations were normalized with the protein contents in the supernatants. The results of $\mathrm{tPA}$ and PAI-I parameters were described as $\mathrm{ng} / \mathrm{mg}$ protein.

\section{Statistical Analyses}

Mann Whitney $U$ test was used for comparisons among the groups. $P<0.05$ was considered significant. All statistical analyses were performed with the Statistical Package for Social Sciences (SPSS) software for Windows 10.0 (Chicago, Illinois, USA).

\section{RESULTS}

\section{Adhesion Formation (Fig. 1, Tables 2, 4)}

In the normothermic saline lavage group, two animals were adhesion-free. In the other groups, adhesion-free healing was not seen. Adhesion scores were significantly lower in the normothermic saline group than the control and hypothermic saline group ( $p=0.008$ in both). Adhesion scores tended to be lower in hypothermic saline than the control group; however, the difference was not significant $(p=0.515)$.

\section{tPA and PAI-1 (Figs. 2, 3 and Tables 3, 4)}

Sham: Sham group was used to determine the baseline values of peritoneal tPA and PAI-I.

Control: Cecal abrasion caused a progressive decrease

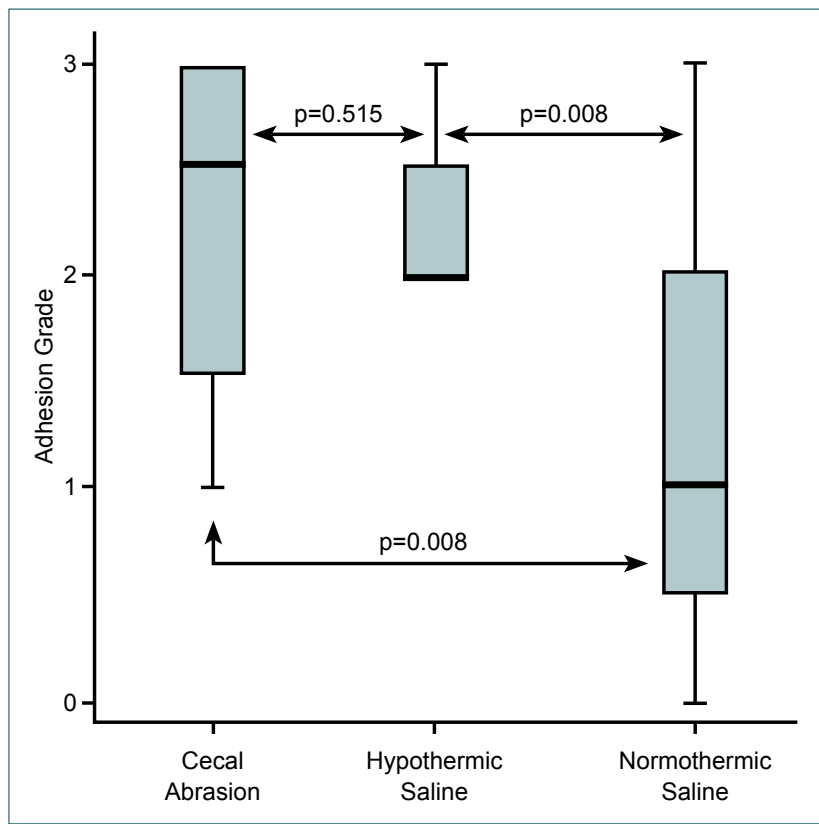

Figure 1. Adhesion scores were evaluated on postoperative day ten. Values are median (horizontal bars) with interquartile range (boxes) and $10-90^{\text {th }}$ centile (error bars). Mann Whitney $U$ test was used.
Table 2. Adhesion grades on postoperative day ten

\begin{tabular}{cccc}
\hline Grade & Control & $\begin{array}{c}\text { Hypothermic } \\
\text { Saline }\end{array}$ & $\begin{array}{c}\text { Normothermic } \\
\text { Saline }\end{array}$ \\
\hline 0 & - & - & 2 \\
1 & 2 & 1 & 3 \\
2 & 2 & 5 & 2 \\
3 & 4 & 2 & 1 \\
Total & 8 & 8 & 8 \\
\hline
\end{tabular}

within 10 days in the median values. Approximately, a tenfold increase was observed in PAI-I levels on postoperative day I. However, PAI-I levels returned to baserline levels on days 3 and 10.

Hypothermic saline: On postoperative day I, the median values of tPA were increased by 72 percent compared to the baseline values. On day 3 , the median tPA values decreased slightly below the baseline. Subsequently, the median values of tPA in hypothermic saline nearly approached to the baseline values on day 10. Hypothermic saline lavage caused lesser

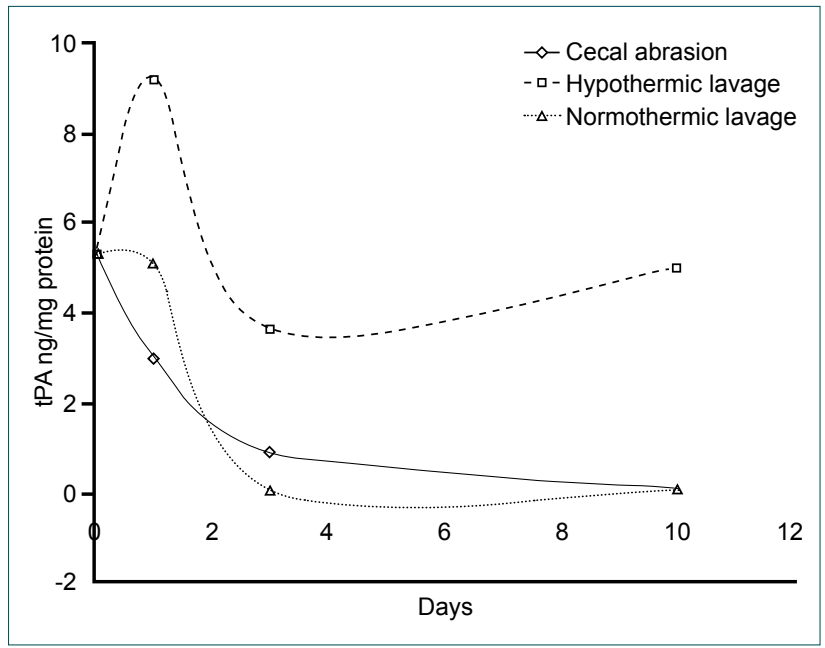

Figure 2. Peritoneal tPA concentration change by groups and days.

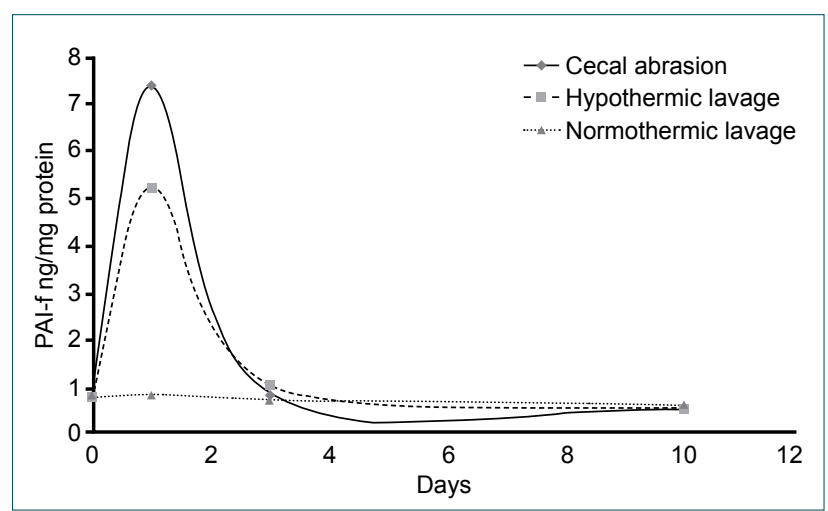

Figure 3. Peritoneal PAI-1 concentration change by groups and days. 
Table 3. tPA levels in peritoneal tissue (ng/mg protein) at postoperative days I, 3 , and 10. Data are presented as median (min-max). $\mathrm{p}$ values are concerning about the comparisons between control and experimental groups

\begin{tabular}{lcccc}
\hline & $\mathbf{t P A}^{\mathbf{0}}$ & $\mathbf{t P A}^{\prime}$ & $\mathbf{t P A}^{13}$ & $\mathbf{t P A}^{\mathbf{1 0}}$ \\
\hline Sham & 5.3 & - & - & - \\
& $(0.5-13.1)$ & & & 0.1 \\
Control & - & 3 & 0.93 & $(0.1-11.3)$ \\
& - & $(0.5-19.8)$ & $(0.1-17.4)$ & 5 \\
Hypo saline & & 9.15 & 3.65 & $(0.1-27)$ \\
& - & $(3.4-24.9)$ & $(0.1-10.7)$ & $\mathrm{P}=0.007$ \\
Normo saline & & $\mathrm{P}=0.034$ & $\mathrm{p}=0.287$ & 0.1 \\
& & 5.1 & 0.1 & $(0.1-12.3)$ \\
& & $(0.55-16.30)$ & $(0.1-8.1)$ & $\mathrm{P}=0.664$ \\
\hline
\end{tabular}

Table 4. PAI- I levels in peritoneal tissue ( $\mathrm{ng} / \mathrm{mg}$ protein) at postoperative days I, 3 , and 10. Data are presented as median (min-max). $\mathrm{P}$ values are concerning about the comparisons between control and experimental groups

\begin{tabular}{|c|c|c|c|c|}
\hline & PAI- $\left.\right|^{0}$ & PAI-I' & PAI- $I^{3}$ & PAI-I ${ }^{10}$ \\
\hline \multirow[t]{2}{*}{ Sham } & 0.78 & - & - & - \\
\hline & $(0.75-0.80)$ & & & \\
\hline \multirow[t]{2}{*}{ Control } & - & 7.40 & 0.85 & 0.58 \\
\hline & & $(0.85-23.6)$ & $(0.5-17)$ & $(0.55-0.65)$ \\
\hline \multirow[t]{3}{*}{ Hypo saline } & - & 5.25 & 1.08 & 0.58 \\
\hline & & $(0.8-39.1)$ & $(0.85-6.8)$ & $(0.5-0.7)$ \\
\hline & & $p=0.364$ & $p=0.68$ & $p=0.313$ \\
\hline \multirow[t]{3}{*}{ Normo saline } & - & 0.88 & 0.75 & 0.63 \\
\hline & & $(0.8-3.5)$ & $(0.7-0.8)$ & $(0.55-0.8)$ \\
\hline & & $\mathrm{p}<0.00 \mathrm{I}$ & $\mathrm{p}=0.00 \mathrm{I}$ & $p=0.038$ \\
\hline
\end{tabular}

increase on day I PAI-I values. The increase was around sevenfold.

Normothermic saline: Median tPA values were similar with the sham group on day I. On day 3 , the median values decreased slightly lower than the control animals and persisted at the same values on day 10. Normothermic saline lavage prevented the increase in PAI-I evident on day I in abrasion and hypothermic lavage groups. Postoperative measurements of PAI-I on days I, 3, and I0 were similar to baseline values in this group.

\section{DISCUSSION}

Reduced peritoneal adhesion formation was demonstrated following lavage with normothermic $\left(37^{\circ} \mathrm{C}\right)$ saline. Suppression of trauma-induced PAI-I rise indicates augmented fibrinolysis within peritoneum with normothermic saline. Hy- pothermic lavage $\left(21^{\circ} \mathrm{C}\right)$ also caused inhibition of PAI-I and improved adhesion slightly but insignificantly. However, PAI-I inhibition was less than that of normothermic lavage.

Peritoneal healing differs from that of skin..$^{[7]}$ The two main differences are epithelization and consequences of fibrin deposition. Firstly, peritoneal epithelization takes place throughout the entire surface of the defect simultaneously. Thus, peritoneum does not have to be approximated by sutures to ensure prompt healing. Differently, skin epithelization results from the migration of epithelial cells from dermal edges. Secondly, fibrin matrix that forms after peritoneal injury is broken down via peritoneal fibrinolysis and is absorbed under normal circumstances. However, fibrin matrix is organized to scar tissue in skin healing. It is also suggested that adhesive scar tissue is a normal part of peritoneal healing and that if the fibrin matrix is broken down via peritoneal fibrino- 
lysis and absorbed within 2-3 days of surgery, then normal (adhesion free) healing might occur. Peritoneum has an inherent fibrinolytic activity similar to that found in vascular endothelium. ${ }^{[8]}$ In adhesion-free peritoneal healing, there is a balance between fibrinogenesis and fibrinolysis. If fibrin exudate overwhelms fibrinolytic activity, organization leading to adhesion rather than resolution of the fibrin-cellular matrix occurs. Peritoneal fibrinolysis parameters (tPA and PAI-I) are potential markers for the identification of patients at risk for developing adhesions.

Peritoneal hypoxia and acidosis (vasoconstriction induced) cause apoptosis of mesothelial cells. Apoptosis leads to the denuded peritoneal areas. This nudity reduces peritoneal fibrinolysis and facilitates adhesion formation into the submesothelial connective tissue. ${ }^{[4]}$

The most popular strategy used for adhesion reduction is the use of irrigation with crystalloid solutions during either open or laparoscopic surgery. Despite the widespread use of intraoperative peritoneal lavage, there is little information on the ideal temperature of the fluid. In review of the literature, we could not identify any study which examined comparatively the effect of normothermic and hypothermic (approximate operating room temperature i.e. $21^{\circ} \mathrm{C}$ ) saline lavage on peritoneal adhesions.

The work of Kappas et al. is relatively similiar to ours. They have designed a study to examine the influence of saline irrigation at different temperatures $\left(30^{\circ} \mathrm{C}, 34^{\circ} \mathrm{C}, 37^{\circ} \mathrm{C}, 40^{\circ} \mathrm{C}\right.$, $45^{\circ} \mathrm{C}, 55^{\circ} \mathrm{C}$ and $60^{\circ} \mathrm{C}$ ) on adhesion formation in the rat laparotomy incision. ${ }^{[9]}$ Laparotomy - without any adhesion inducing activity different from our study- has been followed by intraperitoneal normal saline irrigation for $5 \mathrm{~min}$ with $40 \mathrm{ml}$ volume. Macroscopic assessment of adhesions to the laparotomy scar has been graded. They have shown that adhesion formation increases when the temperature of saline exceeds $37^{\circ} \mathrm{C}$. Saline irrigation with $30^{\circ} \mathrm{C}, 34^{\circ} \mathrm{C}$ and $37^{\circ} \mathrm{C}$ temperature does not prevent adhesions to midline incision, unlike our findings.

Sortini et al. have evaluated different peritoneal lavage solutions following Escherichia coli inoculation inside the rat peritoneal cavity for $10 \mathrm{~min}$ to test their (lavage solutions) ability to prevent adhesion formation. ${ }^{[10]}$ They have observed that peritoneal lavage with $37^{\circ} \mathrm{C}$ saline solution is associated with low adhesion formation and high survival rates as compared to twice-distilled water and antiseptics. However, the group of $37^{\circ} \mathrm{C}$ saline lavage was the control group itself, and mechanical cleansing by use of swabs or hypothermic saline lavage was not applied as control. Although the results were similar to ours, their model was an intra-abdominal sepsis and differed from the peritoneal adhesion models that we used.

Temperatures of saline and other solutions applied in peritoneal adhesion models were not specified in previous studies.
It is reasonable to assume that these lavage solutions are at room temperature. On the other hand, saline is used generally as control in the peritoneal adhesion models of intraabdominal medication. When saline lavage or installation is included into the experimental groups, three different results are observed; beneficial, ${ }^{[10-14]}$ ineffective,$^{[9,15-18]}$ or even harmful. ${ }^{[19,20]}$

Another challenge in peritoneal adhesion studies is the use of several different models. Two major problems caused by peritoneal adhesions are intestinal obstruction and infertility. Therefore, two main experimental models of peritoneal adhesion formation have been utilized. While intestinal- peritoneal abrasion, intestinal anastomosis or peritonitis represents surgical models, gynecologic models include uterine horn injury (cauterization, anastomosis) or ovary cauterization. Though saline irrigation is explored in gynecological and surgical models separately, the uncertainty about its effect on peritoneal adhesions continues.

Panahi et al. have evaluated the effect of normal saline and methylene blue on postoperative adhesion formation in a rat cecal abrasion model similar to ours. ${ }^{[14]}$ They have demonstrated reduced adhesion scores following $\mathrm{I} \mathrm{ml}$ of saline installation. However, in another experimental rat model of small intestine abrasion with jejunal resection-reanastomosis, intraperitoneal administration of a $6 \mathrm{ml}$ saline has not had any effect on adhesion formation. ${ }^{[15]}$ Lavage temperature has not been not specified in these studies, as well.

One mesothelial culture study has shown that incubation with normal saline solution for $6 \mathrm{~h}$ decreases tPA release, increases PAI-I synthesis, and causes shrinking of the mesothelial cells. ${ }^{[20]}$ van Westreenen et al. have also suggested stimulation of intraperitoneal adhesions with perioperative lavage. ${ }^{[19]}$ In this rat study, uterine horns were attached to the suture placed lateral to the wall of the abdomen, and 10 $\mathrm{ml}$ of lavage $\left(25^{\circ} \mathrm{C}\right)$ for 10 min was applied. The lavage solutions were normal saline, povidone-iodine I\%, chlorhexidine $0.02 \%$, RPMI growth (cell culture) medium, and UW (University of Wisconsin solution).

Peritoneum has an inherent fibrinolytic activity similar to that found in vascular endothelium. Increased PAI-I levels in both peritoneal samples and peritoneal fluid or lavage are associated with higher peritoneal adhesion incidences, probably encountering the most important determinant. ${ }^{[I]}$ Indeed in our animal model, normothermic saline lavage reduced PAI-I elevations to normal levels in injured peritoneal tissue most likely preventing peritoneal hypothermia, hypoxia and acidosis. In conclusion, the improvement of peritoneal fibrinolysis reduced adhesions.

\section{Acknowledgement}

The authors wish to thank Mekin SEZIK M.D. from the De- 
partment of Obstetrics and Gynecology, Faculty of Medicine, Suleyman Demirel University, for language revisions.

\section{Conflict of interest: None declared.}

\section{REFERENCES}

1. Ellis H, Moran BJ, Thompson JN, Parker MC, Wilson MS, Menzies D, et al. Adhesion-related hospital readmissions after abdominal and pelvic surgery: a retrospective cohort study. Lancet 1999;353:1476-80.

2. Scott-Coombes DM, Vipond MN, Thompson JN. General surgeons' attitudes to the treatment and prevention of abdominal adhesions. Ann R Coll Surg Engl 1993;75:123-8.

3. Eddy VA, Morris JA Jr, Cullinane DC. Hypothermia, coagulopathy, and acidosis. Surg Clin North Am 2000;80:845-54.

4. Tarhan OR, Barut I, Ozogul C, Bozkurt S, Baykara B, Bulbul M. Structural deteriorations of the human peritoneum during laparoscopic cholecystectomy. A transmission electron microscopic study. Surg Endosc 2013;27:2744-50.

5. Akdeniz Y, Tarhan OR, Barut I. Can dexpanthenol prevent peritoneal adhesion formation? An experimental study. [Article in Turkish] Ulus Travma Acil Cerrahi Derg 2007;13:94-100.

6. Lowry OH, Rosebrough NJ, Farr AL, Randall RJ. Protein measurement with the Folin phenol reagent. J Biol Chem 1951;193:265-75.

7. diZerega GS, Campeau JD. Peritoneal repair and post-surgical adhesion formation. Hum Reprod Update 2001;7:547-55.

8. Gervin AS, Puckett CL, Silver D. Serosal hypofibrinolysis. A cause of postoperative adhesions. Am J Surg 1973;125:80-8.

9. Kappas AM, Fatouros M, Papadimitriou K, Katsouyannopoulos V, Cassioumis D. Effect of intraperitoneal saline irrigation at different temperatures on adhesion formation. Br J Surg 1988;75:854-6.

10. Sortini D, Feo CV, Maravegias K, Carcoforo P, Pozza E, Liboni A, et al.
Role of peritoneal lavage in adhesion formation and survival rate in rats: an experimental study. J Invest Surg 2006;19:291-7.

11. Kucukozkan T, Ersoy B, Uygur D, Gundogdu C. Prevention of adhesions by sodium chromoglycate, dexamethasone, saline and aprotinin after pelvic surgery. ANZ J Surg 2004;74:1111-5.

12. Tarhan OR, Barut I, Sezik M. An evaluation of normal saline and taurolidine on intra-abdominal adhesion formation and peritoneal fibrinolysis. J Surg Res 2008;144:151-7.

13. Kalaycı MU, Eroğlu HE, Kubilay D, Soylu A, Sancak B, Uğurluoğlu C, et al. The effects of methylene blue on adhesion formation in a rat model of experimental peritonitis. Ulus Travma Acil Cerrahi Derg 2011;17:205-9.

14. Panahi F, Sadraie SH, Khoshmohabat H, Shahram E, Kaka G, Hosseinalipour M. Macroscopic and pathological assessment of methylene blue and normal saline on postoperative adhesion formation in a rat cecum model. Int J Surg 2012;10:537-41.

15. Lai HS, Chu SY, Chen Y, Wu CH, Lin LT. Effect of pentoxifylline on intraperitoneal adhesions after intestinal resection in rats. J Formos Med Assoc 1994;93:911-5.

16. Treutner KH, Bertram P, Lerch MM, Klimaszewski M, Petrovic-Källholm S, Sobesky J, et al. Prevention of postoperative adhesions by single intraperitoneal medication. J Surg Res 1995;59:764-71.

17. Cavallari N, Polistena A, Cavallaro A. Inability of University of Wisconsin solution to reduce postoperative peritoneal adhesions in rats. Eur J Surg 2000;166:650-3.

18. Kayaoğlu HA, Ozkan N, Yenidoğan E, Köseoğlu RD. Effect of antibiotic lavage in adhesion prevention in bacterial peritonitis. Ulus Travma Acil Cerrahi Derg 2013;19:189-94.

19. van Westreenen M, van den Tol PM, Pronk A, Marquet RL, Jeekel J, Leguit P. Perioperative lavage promotes intraperitoneal adhesion in the rat. Eur Surg Res 1999;31:196-201.

20. Połubinska A, Winckiewicz M, Staniszewski R, Breborowicz A, Oreopoulos DG. Time to reconsider saline as the ideal rinsing solution during abdominal surgery. Am J Surg 2006;192:281-5.

\title{
DENEYSEL ÇALIŞMA - ÖZET
}

\section{Serum fizyolojikle yapılan lavaj sıcaklığının peritoneal fibrinoliz ve adezyon gelişimine etkisi}

\section{Dr. Yavuz Savaş Koca, ${ }^{1}$ Dr. Ömer Rıdvan Tarhan, ${ }^{1}$ Dr. Selçuk Kaya, ${ }^{2}$ Dr. Berit Gökçe Ceylan ${ }^{3}$}

\author{
${ }^{1}$ Süleyman Demirel Üniversitesi Tıp Fakültesi, Genel Cerrahi Anabilim Dalı, Isparta \\ ${ }^{2}$ Süleyman Demirel Üniversitesi Tıp Fakültesi, Tıbbi Mikrobiyoloji Anabilim Dalı, Isparta \\ ${ }^{3}$ Süleyman Demirel Üniversitesi Tıp Fakültesi, Anesteziyoloji ve Reanimasyon Anabilim Dalı, Isparta
}

AMAÇ: Oda sıcaklı̆ındaki serum fizyolojikle yapılan periton lavajı peritonda hipotermi, vazokonstriksiyon, hipoksi ve asidoza neden olur. Bu etkilerin fibrinolizi azalttığı bilinmektedir. Fibrinolizin bozulması ise kalıcı adezyona neden olmaktadır. Normotermik lavaj bu zararlı süreci engelleyerek peritoneal adezyonları azaltabilir.

GEREÇ VE YÖNTEM: Sıçan çekal abrzyon modeli kullanıldı. Kontrol hayvanlarına herhangi bir tedavi uygulanmazken, deney gruplarına (her birinde $n=24$ ) hipotermik ve normotermik serum fizyolojik ile lavaj uygulandı. Ameliyat sonrası bir, üç ve onuncu günlerde periton dokusunda peritoneal fibrinolizin ana parametreleri olan doku plazminojen aktivatörü (tPA) ve plazminojen aktivatör inhibitor tip-I (PAI-I) bakıldı. Adezyonlar ameliyat sonrası 10. günde değerlendirildi. Sham grubunda $(n=8)$ laparotomi sonrası periton örnekleri alındı ve sağıklı peritondaki bazal tPA ve PAI-I değerleri tespit edildi.

BULGULAR: Çekal abrazyon, PAI-I düzeylerini ameliyat sonrası birinci günde yaklaşık 10 kat kadar artırarak adezyonlara neden oldu. Normotermik serum fizyolojik ile lavaj bu travmatik PAI-I artışını engelleyerek deney boyunca normal seviyeye sabitledi ve adezyon gelişimini azalttı. Hipotermik lavaj da PAI-I yükselişini azalttı ancak adezyonların önlenmesi istatistiksel olarak anlamlı değildi.

TARTIŞMA: Sonuçlarımız göstermektedir ki, normotermik serum fizyolojik ile lavaj peritoneal fibrinolizi düzelterek adezyonları azaltmaktadır. Anahtar sözcükler: Hypothermic; normothermic; peritoneal adhesion; peritoneal lavage; plasminogen activator inhibitor I; saline solution; tissue plasminogen activator.

Ulus Travma Acil Cerrahi Derg 2016;22(I):I-6 doi: 10.5505/tjtes.2015.9588| 